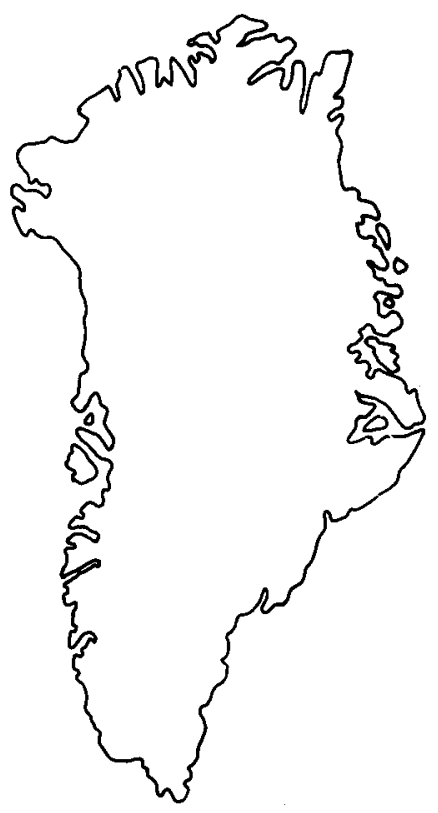

\title{
A lamproite stock with ellipsoidal phlogopite nodules at Oqaitsúnguit, Disko Bugt, central West Greenland
}

\author{
Lilian Skjernaa
}

\begin{abstract}
A small stock containing a medium- to coarse-grained phlogopite-rich lamproite occurs in the Archaean Atâ granitoid in West Greenland. It was emplaced by a combination of forceful intrusion and assimilation. Metasomatic alteration has taken place in the country rock near the stock and in xenoliths.

Although there are similarities with other lamproites, the Oqaitsúnguit lamproite differs with respect to (1) mineralogy. The main mineral phases are phlogopite, microcline, $\mathrm{K}$-richterite, $\mathrm{K}-\mathrm{Mg}$-arfvedsonite, aegirine-augite and diopside; (2) coarse grain size; (3) low whole-rock $\mathrm{TiO}_{2}, \mathrm{FeO}$ and $\mathrm{SiO}_{2}$ contents; (4) low $\mathrm{TiO}_{2}$ in phlogopites and amphiboles; (5) the presence of $0.5-6 \mathrm{~cm}$ long ellipsoidal phlogopite nodules, which occur scattered throughout the rock.

Each phlogopite nodule is composed of a central phlogopite grain, which is enveloped by a mantle or shell of another phlogopite grain.
\end{abstract}

L. S., Geological Institute, University of Copenhagen, Øster Voldgade 10, DK-1350 Copenhagen K, Denmark.

A small stock of an unusual alkaline mafic rock was discovered in West Greenland in 1989. The occurrence is located $100 \mathrm{~m}$ above sea level at the northern part of the cape Oqaitsúnguit (Fig. 1), about $60 \mathrm{~km}$ north of Ilulissat/Jakobshavn.

The rock is rich in phlogopite and contains $\mathrm{K}$-feldspar and K-richterite; mineralogically and chemically it resembles a lamproite (Mitchell, 1985; Bergmann, 1987; Rock, 1987). It also contains ellipsoidal phlogopite nodules with a unique internal structure.

Rocks of the lamproite family are fairly rare in Greenland. The nearest known occurrence is situated in the Holsteinsborg area $350 \mathrm{~km}$ to the south (Scott, 1979, 1981).

This paper documents the occurrence of this unusual rock type and presents preliminary data necessary to characterise it, together with a detailed description of its phlogopite nodules.

\section{Regional geology}

The country rock intruded by the lamproite stock is part of the Atâ granitoid complex (Escher \& Burri, 1967; Knudsen et al., 1988) which has yielded radiometric ages of c. $2800 \mathrm{Ma}$ (Kalsbeek et al., 1988). At Oqaitsúnguit it is a plagioclase-porphyric biotite granodiorite, while in other parts of the complex it has a tonalitic composition. The central parts of the Atâ pluton are not deformed and often show a magmatic layering which, in the area around the lamproite stock, shows low to moderate dips in variable directions (Fig. 1). Towards the margins, especially towards the south and south-east, the granitoids show increasing evidence of plastic folding, probably indicating at least two phases of deformation (Fig. 1).

The Atâ granitoids, as well as the surrounding gneisses, are cut by subvertical ultramafic lamprophyre dykes. The dykes seem to have intruded into a preexisting or contemporaneous regional joint system (Fig. 1) and to have caused extensive alteration of the wall rocks. Similar dykes are described by Marker \& Knudsen (1989) from the area to the east.

A genetic relationship between the lamprophyre dykes and the lamproite stock seems probable as $\mathrm{K}-\mathrm{Ar}$ age determinations have shown that these rocks are of the same age, around $1750 \mathrm{Ma}$ (Larsen \& Rex, in press). K-Ar age determinations on one of the phlogopite nodules also give $c .1750 \mathrm{Ma}$ as a preliminary result (H. Rasmussen, unpublished data).

\section{Field occurrence}

The lamproitic rock crops out in two places which are separated by approximately $20 \mathrm{~m}$ of country rock (Figs 1 


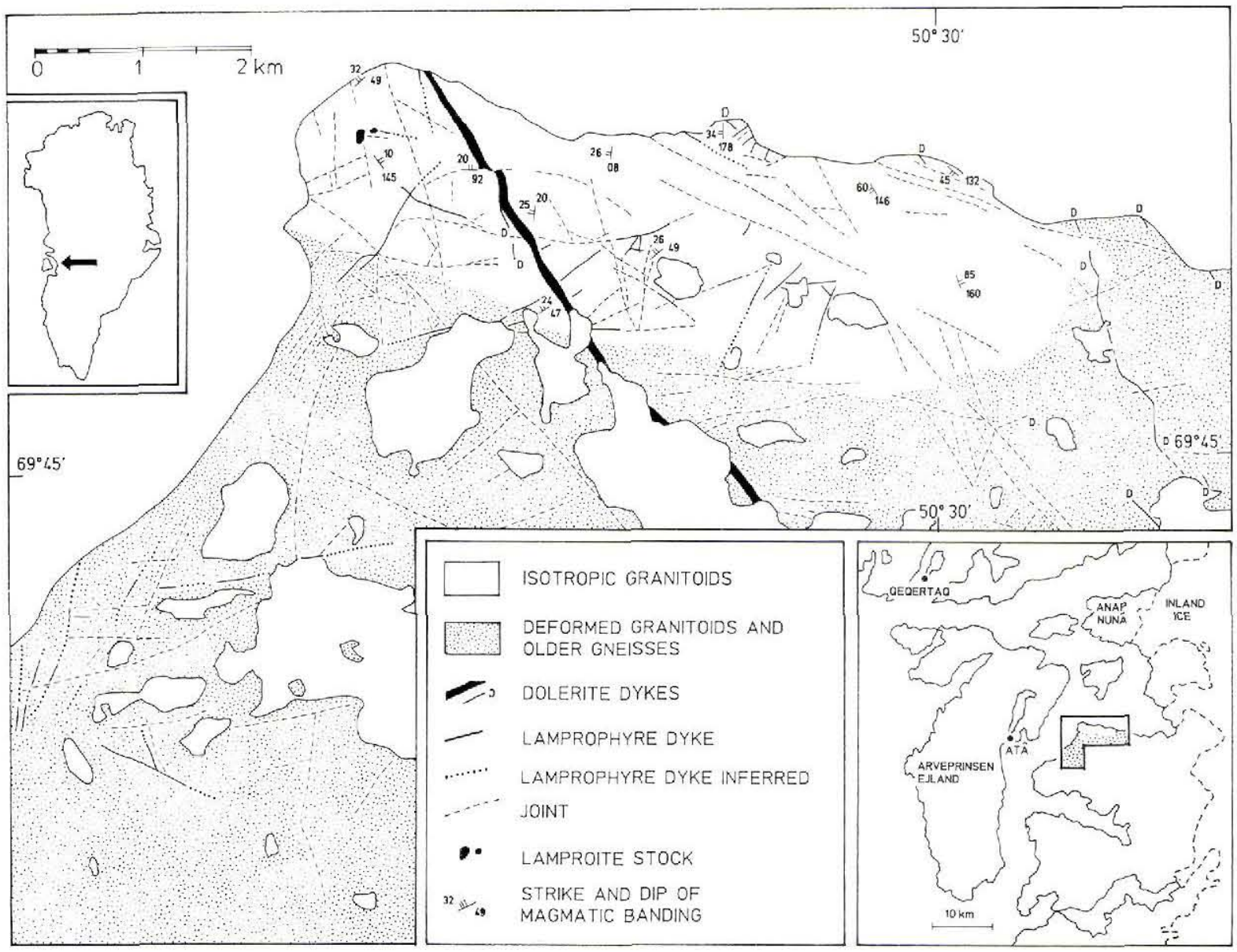

Fig. 1. Geological map of the Oqaitsúnguit area, Atâ region, West Greenland.

and 2). The two occurrences are probably connected at depth. The larger outcrop is about $75 \times 50 \mathrm{~m}$, while the smaller eastern occurrence is only about $10 \times 15 \mathrm{~m}$ and seems to continue towards the east in a dyke, which is, however, almost completely covered.

The stock was emplaced by forceful intrusion; the country rock is strongly brecciated, and fragments of it are enclosed in the lamproite, with concentrations towards the margins. Both the xenoliths and the country rock have been metasomatically altered to such a degree that the original mineral assemblages have been replaced by almost the same minerals as the lamproite, but in different proportions (Table 1).

The xenoliths are zoned with an amphibole-rich rim. Some xenoliths have centimetre-sized euhedral crystals of microcline, calcite and K-richterite. Arfvedsonite occasionally forms long radiating needles. Some xenoliths have a pyroxene-rich core surrounded by an amphibolerich rim (Table 1).
Towards the margins of the stocks the lamproite is bluish-green, while it is brown in the centres. The colour difference is a consequence of variations in mineralogy; central areas have more phlogopite and less amphibole, microcline and calcite than the marginal rocks. This difference in composition may indicate that some assimilation of country rock has taken place. Backveining of the altered country rock into the lamproite has also been observed.

In one place an exceptional structure was observed (Fig. 3), which seems to be similar to the 'mushroom' shaped load structures described by Thy \& Wilson (1980). This may indicate the existence of a density contrast between a relatively buoyant assimilated marginal part of the stock and a denser central part.

Although the Oqaitsúnguit lamproite is unusual in itself, its most outstanding feature is the presence of peculiar ellipsoidal phlogopite nodules. 


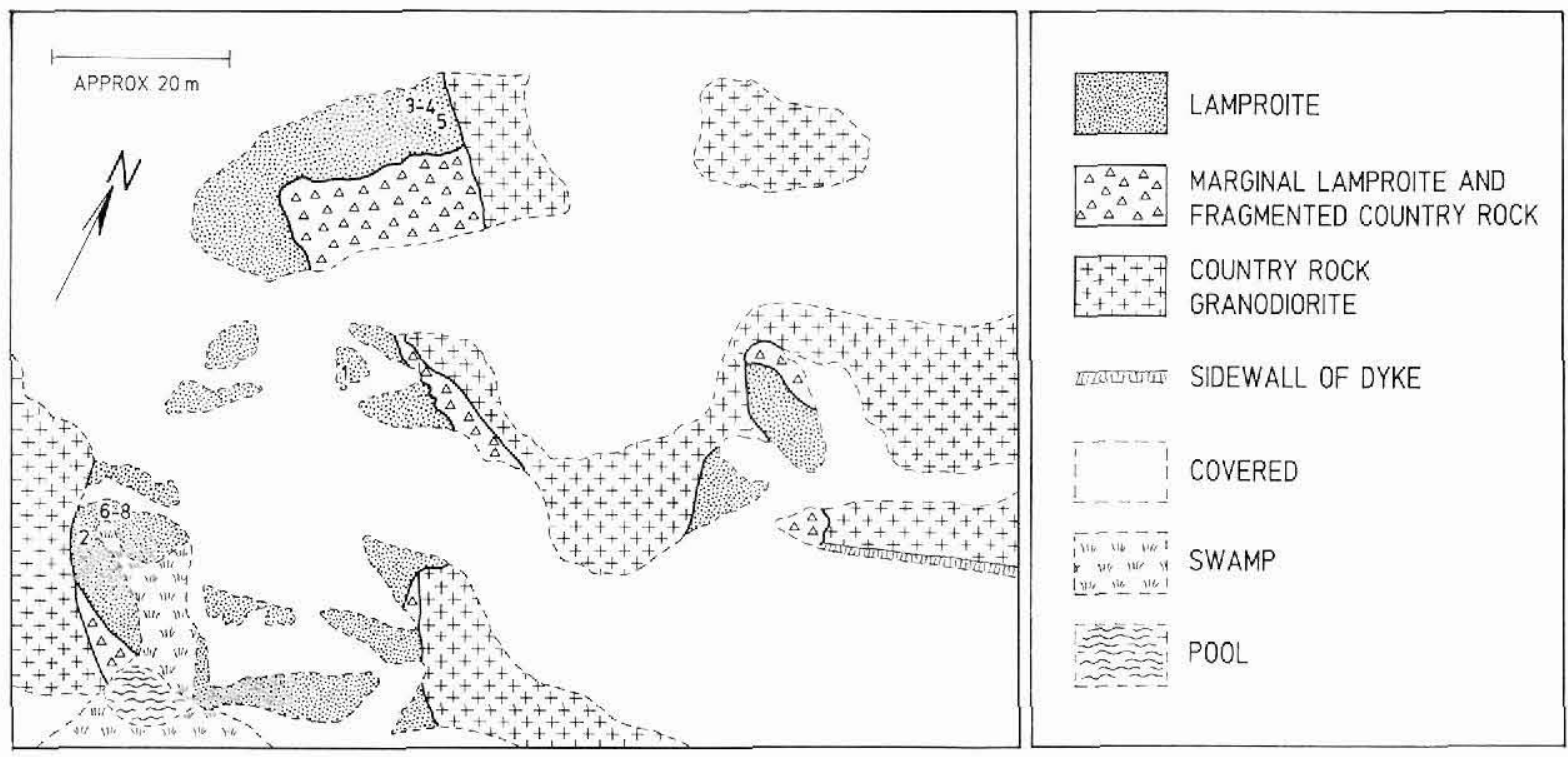

Fig. 2. Geological map showing the outcrop pattern of the lamproite stock. The map is drawn from a field sketch and is not to scale. The numbers mark the sites of the samples mentioned in Table 1.

\section{Ellipsoidal phlogopite nodules}

Dark-brown, lustrous, $0.5-6 \mathrm{~cm}$ large nodules of monomineralic phlogopite are scattered throughout both the central and marginal parts of the lamproite stock. They are spaced some centimetres or decimetres apart. They have not been observed as inclusions in xenoliths, but in some cases clusters of nodules are found near to xenoliths (Fig. 4a).

At the surface weathering has released the nodules from the matrix, and they have been washed together into small depressions where they resemble small chocolate eggs in a bowl.

Each nodule consists of a central phlogopite grain which is completely surrounded by a mantle grain (Figs 4 and 5). The mantle grain is divided into radiating domains to compensate for the curvature that enables the (001) crystallographic plane of the mantle grain everywhere to be parallel to the outer boundary of the central grain (Fig. 5). Each nodule thus essentially consists of two phlogopite grains, one central grain with a normal platy crystal structure and one mantle grain which completely envelopes the central grain. The central grains may show zoning and polysynthetic twins and contain small but varying amounts of included microcline. calcite, pyroxene and sphene. Most often the (001) crystallographic plane of the central grain is parallel with the plane defined by the largest and intermediate morphological axes of the ellipsoid (Figs $4 e-h$ ). More rarely the central grain has a rounded outline and
(001) planes oblique to the morphologic axes of the ellipsoid (Fig. 4b).

The mantle grains are zoned; under the microscope the zones are seen to form continuous rings, i.e. they are shells in three dimensions around the central grains. The same applies to the cleavage surfaces (Figs 4 and 5). Within each domain of the mantle shell the lattice is bent as much as about $5^{\circ}$ without losing its continuity. The boundaries between the domains are characteristically serrate (Figs 4e, g and 5) and are partly lined by

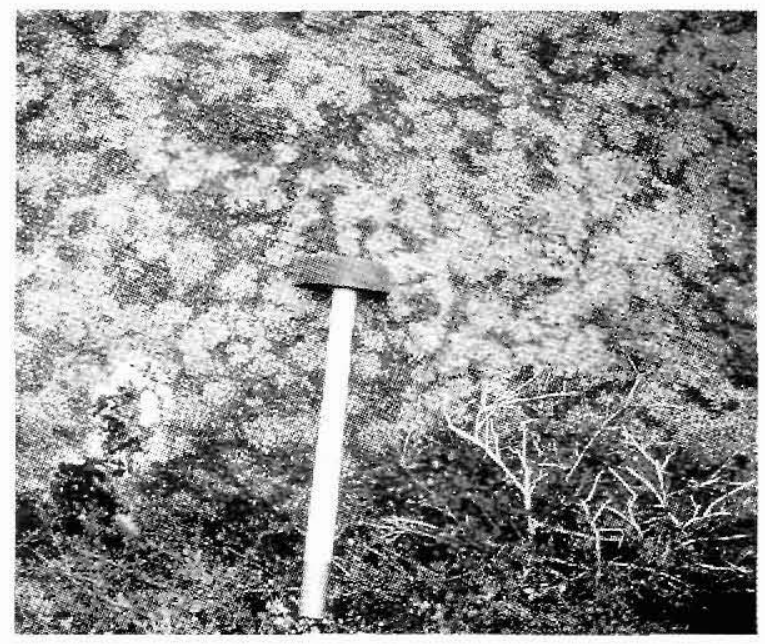

Fig. 3. 'Mushroom' structures developed at the boundary between dark phlogopite-rich central type lamproite and amphibole-rich margin type lamproite. The hammer is $50 \mathrm{~cm}$ long. 

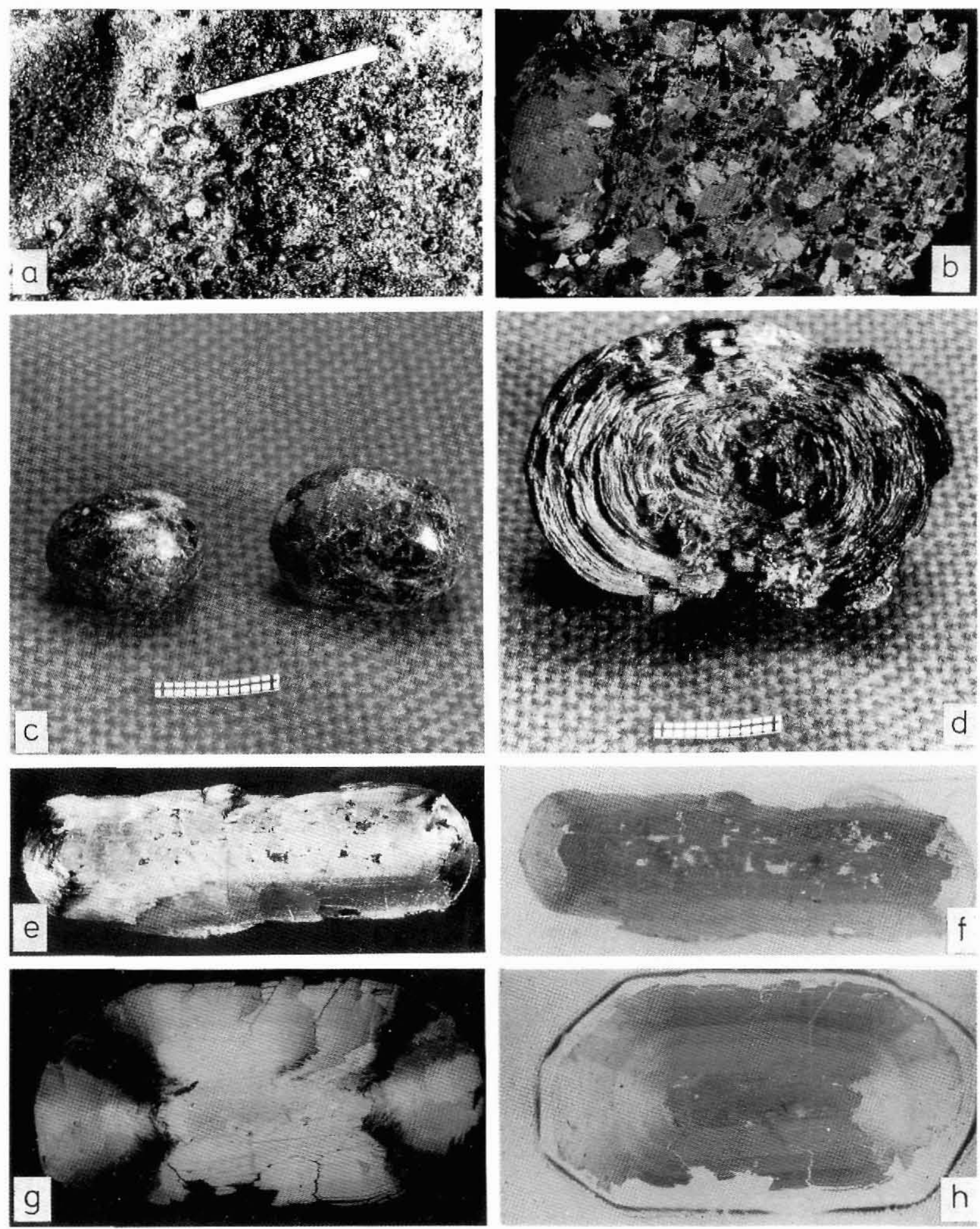

Fig. 4. (a) Lamproite with cluster of phlogopite nodules. Part of a xenolith is seen in the upper left corner. The pen is $13 \mathrm{~cm}$ long. (b) Thin section (crossed polars) of lamproite with phlogopite nodule to the left, GGU 343955. The horizontal length of the thin section is $4 \mathrm{~cm}$. (c) and (d) show shape and internal structure of three phlogopite nodules, scale bars are $1.2 \mathrm{~cm}$. (e)-(h) are thin sections of two phlogopite nodules, (e) and (g) seen through crossed polars and (f) and (h) in plane polarized light. Both nodules are cut parallel to the major and minor morphological axes. (e) and (f) show a $1.7 \mathrm{~cm}$ long and $0.5 \mathrm{~cm}$ wide nodule that has a large central grain with numerous inclusions of microcline and calcite, $(\mathrm{g})$ and $(\mathrm{h})$ show a $2.5 \mathrm{~cm}$ long and $1.3 \mathrm{~cm}$ wide nodule with a relatively small central grain with few inclusions. This nodule is the same as shown in Fig. 5. (c)-(h): GGU 343959. 


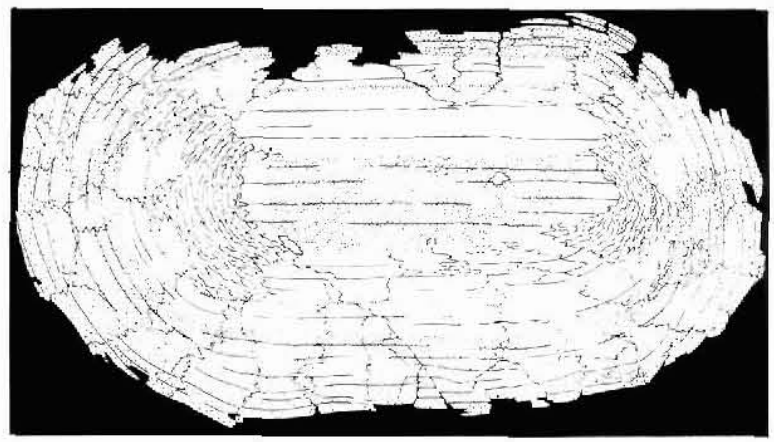

$\begin{array}{llllll}0 & 5 & 10 & 15 & 20 & 25\end{array}$

Fig. 5. Drawing of a thin section of a phlogopite nodule (same as shown on Fig. $4 \mathrm{~g}$ and $\mathrm{h}$ ). The section is at right angles to the (001) crystallographic plane of the central grain and parallel with the plane defined by the longest and shortest morphological axes of the nodule. Notice the contimuous (001) cleavage and colour zoning of the mantle around the central grain and the small subgrains in the mantle at the ends of the central grain. Also notice the zonarity of the central grain.

small sub-grains. They may also take the form of kink bands. In a few cases small new recrystallised grains with discordant lattice orientations are seen at domain boundaries.

The mantle grain has grown in lattice continuity with the (001) crystallographic surfaces of the central grain, but elsewhere the lattice orientations of the central grain and the mantle grain are discordant by up to $90^{\circ}$.

Where the curvature of the mantle grain is greatest, i.e. at the blunt terminations of the central grain, it consists of numerous, small sub-grains, but even here zonation and cleavage may be traceable almost continuously, except for small jumps over sub-grain boundaries (Fig. 5). In a few cases more extensive recrystallisation has occurred in the mantle grain, or the mantle grain have been partly destroyed by the intergrowth of matrix minerals (e.g. amphibole).

The relative dimensions of the central and mantle grains vary. In some nodules a large central grain is surrounded by a thin mantle grain (Figs $4 e$ and $f$ ), while in others the central grain is tiny and the mantle grain constitutes most of the nodule (Fig. 4d). Similarly, the relative dimensions of the three principal axes of the ellipsoidal nodules vary within wide limits, but appear to be governed by the shape of the central grains.

The chemical characteristics of the nodules are described below.

\section{Petrography and mineral compositions}

The lamproite which forms the matrix to the phlogopite nodules is a medium-grained, texturally isotropic rock (Figs $4 \mathrm{a}, \mathrm{b}$ ). It is composed of more than $50 \%$ phlogopite, with $15-25 \%$ microcline, 1-15\% amphibole (K-richterite and $\mathrm{K}-\mathrm{Mg}$-arfvedsonite), $0-15 \%$ pyroxene (diopside and aegirine-augite), $0-10 \%$ calcite, $2-10 \%$ apatite and small amounts of either sphene or rutile (Table 1).

The phlogopite in the matrix occurs as randomly oriented, up to $0.5 \mathrm{~cm}$ long, subhedral-euhedral phenocrysts. The microcline and some of the amphibole form very large $(0.5-2 \mathrm{~cm})$ poikilitic grains that enclose all the other mineral phases.

Pyroxene is most abundant in the centre of the stock (Table 1, analysis 1). In the marginal parts, the pyroxenes have been replaced by amphiboles, apparently first by $\mathrm{K}$-richterite and still closer to the contact by $\mathrm{K}-\mathrm{Mg}$ arfvedsonite. Calcite appears only to occur in the marginal parts of the stock. More or less the same mineral

\section{Table 1. Estimated modal composition of samples from the Oqaitsunguit lamproite stock}

\begin{tabular}{|c|c|c|c|c|c|c|c|c|}
\hline & $1^{*}$ & $2^{*}$ & $3^{* \prime}$ & $4^{*}$ & 5 & $6^{\circ}$ & 7 & 8 \\
\hline Phlogopite & $>$ & $>$ & $>$ & & + & $x$ & $\mathrm{x}$ & $<$ \\
\hline microcline & + & + & + & $\mathrm{x}$ & $>$ & $>$ & $>$ & $>$ \\
\hline aegirine-augite & $x$ & & & + & $<$ & & + & \\
\hline diopside & $<$ & & & + & $\mathrm{x}$ & & + & \\
\hline $\mathrm{K}$-richterite & $<$ & + & $<$ & $x$ & + & $x$ & $x$ & $<$ \\
\hline $\mathrm{K}$-Mg-arfvedsonite & & $<$ & $<$ & + & $<$ & $\mathrm{x}$ & & $>$ \\
\hline calcite & & $x$ & & + & $x$ & + & $x$ & + \\
\hline apatite & $x$ & $x$ & & $<$ & $\mathrm{x}$ & $\mathrm{x}$ & $x$ & $x$ \\
\hline sphene & $<$ & & & $<$ & $<$ & & $<$ & \\
\hline rutile & & $<$ & & & & $<$ & & \\
\hline opaque minerals & $<$ & & & & & $<$ & & \\
\hline quartz & & & & $x$ & & & & \\
\hline
\end{tabular}

1: GGU 343955 lamproite from central part of stock.

2: GGU 341609 lamproite from margin of stock.

3: GGU 341606, a lamproite at contact to xenolith (not representative as it only occupies a small part of the thin section).

4: GGU 341606,b xenolith.

5: GGU 341606,c lamproite from margin of stock.

6: GGU 341604 xenolith.

7: GGU 341608, a central part of a xenolith.

8: GGU 341608 ,h marginal part of same xenolith as in 7 .

$>$ more than $30 \%:+10-30 \% ; \times 2-10 ;<$ less than $2 \%$.

microprobe analyses in addition to optical analyses. 
Table 2. Whole rock composition of the Oqaitsúnguit lamproite from central part of stock

\begin{tabular}{lrlr}
\multicolumn{2}{l}{ Major elements, \% } & \multicolumn{2}{c}{ Trace elements, ppm } \\
\hline $\mathrm{SiO}_{2}$ & 39.65 & $\mathrm{Rb}$ & 348 \\
$\mathrm{TiO}_{2}$ & 1.33 & $\mathrm{Ba}$ & 5770 \\
$\mathrm{Al}_{2} \mathrm{O}_{3}$ & 1.38 & $\mathrm{Sr}$ & 3360 \\
$\mathrm{Fe}_{2} \mathrm{O}_{3}$ & 1.19 & $\mathrm{La}$ & 200 \\
$\mathrm{FeO}$ & 3.42 & $\mathrm{Ce}$ & 455 \\
$\mathrm{MnO}$ & 0.05 & $\mathrm{Nd}$ & 253 \\
$\mathrm{MgO}$ & 19.15 & $\mathrm{Y}$ & 37 \\
$\mathrm{CaO}$ & 5.38 & $\mathrm{Zr}$ & $<50$ \\
$\mathrm{Na}_{2} \mathrm{O}$ & 0.37 & $\mathrm{Nb}$ & 7 \\
$\mathrm{~K}_{2} \mathrm{O}$ & 9.71 & $\mathrm{~Pb}$ & 6 \\
$\mathrm{P}_{2} \mathrm{O}_{5}$ & 2.80 & $\mathrm{Th}$ & 7 \\
$\mathrm{H}_{2} \mathrm{O}$ & 0.62 & $\mathrm{Zn}$ & 94 \\
$\mathrm{CO}_{2}$ & 1.70 & $\mathrm{Cu}$ & 42 \\
& & $\mathrm{Sc}$ & 8 \\
& & $\mathrm{~V}$ & 43 \\
& & $\mathrm{Cr}$ & 1240 \\
& & $\mathrm{Ni}$ & 1010 \\
& & $\mathrm{Ga}$ & 14 \\
& & & \\
$\mathrm{FeO}_{\text {tot }}$ & & & \\
$\mathrm{Mg} \mathrm{no}_{\mathrm{K}_{2} \mathrm{O} / \mathrm{Na}_{2} \mathrm{O} \text { (molar) }}$ & & \\
$\mathrm{K}_{2} \mathrm{O} / \mathrm{Al}_{2} \mathrm{O}_{3}$ (molar) & 0.93 & \\
\hline
\end{tabular}

GGU 269766.

Major elements by GGU's chemical laboratory.

Trace elements by John C. Bailey, Geological Institute,

University of Copenhagen (XRF).

transformations occur in some of the xenoliths, which have pyroxene-rich cores and amphibole-rich rims with calcite. Apatite is ubiquitous and forms up to $1 \mathrm{~mm}$ long prismatic crystals.

A whole-rock geochemical analysis of the central part of the Oqaitsúnguit lamproite is given in Table 2. It should be noted that due to the very large grain size and variable modal composition, the analysis does not necessarily represent a liquid composition.

Although the rock is clearly a lamproite, it differs from published descriptions of other lamproites as mentioned below. However, it differs even more from other related rock types such as lamprophyres and kimberlites (see Scott, 1979, 1981; Mitchell, 1985; Bergman, 1987; Dawson, 1987; Rock, 1987; Thy et al., 1987).

The Oqaitsúnguit lamproite differs from other lamproites in its large grain size, the high proportion of mafic minerals (about $75-85 \%$ ) and especially the high content of phlogopite, and in that the felsic mineral is exclusively microcline. In other lamproites, sanidine, leucite, or pseudoleucite are the most common felsic phases (Bergman, 1987). Chemically the Oqaitsúnguit lamproite is characterised by being low in $\mathrm{SiO}_{2}, \mathrm{TiO}_{2}$, $\mathrm{FeO}, \mathrm{Na}_{2} \mathrm{O}$ and $\mathrm{V}$, and high in $\mathrm{MgO}, \mathrm{Ni}, \mathrm{Sr}$ and $\mathrm{Cr}$. The $\mathrm{Mg}$-number $\left(100 \mathrm{MgO} /\left(\mathrm{MgO}+\mathrm{FeO}_{\mathrm{tot}}\right)\right)$ of 88.4 is higher than those of all the lamproites described by Bergman (1987) and is even well above the 'primary' range given by Rock (1987). The $\mathrm{K}_{2} \mathrm{O} / \mathrm{Na}_{2} \mathrm{O}$ (17.2) and $\mathrm{K}_{2} \mathrm{O} / \mathrm{Al}_{2} \mathrm{O}_{3}(0.93)$ molecular ratios are also notably high. It may be inferred that the analysed rock is a phlogopite cumulate.

When plotted in the geochemical variation diagrams of Bergman (1987), the lamproite from Oqaitsúnguit falls inside the limits of 'diamondiferous suites'.

\section{Mineralogy}

A number of electron microprobe analyses were obtained from two phlogopite nodules and from all the mineral phases observed in thin sections, except the opaque minerals. Samples from the central and marginal parts of the stock and from two xenoliths were analysed. Tables 3-8 show average chemical compositions for the principal minerals. Accessory minerals were analysed in order to verify their identification.

The analyses were performed on a JEOL 733/Superprobe using a Tracor Northern energy dispersive system with an accelerating voltage of $15 \mathrm{kV}$ and a beam current of $2 \mathrm{nA}$.

\section{Phlogopite}

The phlogopite in the matrix of the lamproite is almost free of inclusions, zoned and often exhibits polysynthetic twins. Compared with phlogopite from other lamproitic rocks (Scott 1979, 1981; Mitchell, 1985; Bergman, 1987) Oqaitsúnguit phlogopites have very low $\mathrm{Ti}$ and fairly high $\mathrm{Al}$ and $\mathrm{Mg}$ contents (Tables 3-5, Figs 6 and 7).

In some respects they resemble those from the wyomingite-orendite from Leucite Hills (Mitchell, 1985), but actually the phlogopites in the Oqaitsunguit lamproite more closely resemble those from kimberlites or xenoliths in kimberlites (Bergman, 1987).

In the phlogopite nodules the cores have somewhat lower $\mathrm{MgO}$ contents than the mantles, whereas the matrix phlogopites have $\mathrm{MgO}$ contents similar to or slightly lower than the cores. The opposite variation is seen for total $\mathrm{FeO}$ (Fig. 7). The contents of $\mathrm{Ti}$ and $\mathrm{Cr}$ are consistently higher in the cores than in the mantles of the nodules (Tables 4 and 5). $\mathrm{Mg}$ numbers $(100 \mathrm{Mg}$ / $\left.\left(\mathrm{Mg}+\mathrm{Fe}^{2+}\right)\right)$ are generally high (Tables 3-5). 
Table 3. Microprobe analyses of phlogopite from lamproite stock at Oqaitsúnguit

\begin{tabular}{|c|c|c|c|c|c|c|}
\hline & \multicolumn{2}{|c|}{$\begin{array}{c}\text { centre } \\
\text { of stock }\end{array}$} & \multicolumn{2}{|c|}{$\begin{array}{l}\text { margin } \\
\text { of stock }\end{array}$} & \multicolumn{2}{|c|}{ xenolith } \\
\hline & $\begin{array}{c}\text { average } \\
n=19\end{array}$ & $s d v$ & $\begin{array}{c}\text { average } \\
n=5\end{array}$ & $s d v$ & $\begin{array}{c}\text { average } \\
n=3\end{array}$ & $s d v$ \\
\hline $\mathrm{SiO}_{2}$ & 40.07 & 0.53 & 40.37 & 0.70 & 40.24 & 0.21 \\
\hline $\mathrm{TiO}_{2}$ & 1.90 & 0.29 & 2.18 & 0.51 & 2.09 & 0.29 \\
\hline $\mathrm{Al}_{2} \mathrm{O}_{3}$ & 11.85 & 0.44 & 11.87 & 0.40 & 12.33 & 0.27 \\
\hline $\mathrm{Cr}_{2} \mathrm{O}_{3}$ & 0.33 & 0.22 & 0.35 & 0.30 & 0.21 & 0.19 \\
\hline $\mathrm{FeO}$ & 6.15 & 0.41 & 5.31 & 0.56 & 6.12 & 0.36 \\
\hline $\mathrm{MnO}$ & 0.07 & 0.08 & 0.08 & 0.07 & 0.06 & 0.09 \\
\hline $\mathrm{NiO}$ & 0.00 & 0.00 & 0.00 & 0.00 & 0.01 & 0.00 \\
\hline $\mathrm{MgO}$ & 23.21 & 0.53 & 23.49 & 0.36 & 23.50 & 0.41 \\
\hline $\mathrm{CaO}$ & 0.01 & 0.01 & 0.01 & 0.00 & 0.01 & 0.00 \\
\hline $\mathrm{Na}_{2} \mathrm{O}$ & 0.24 & 0.08 & 0.17 & 0.16 & 0.36 & 0.11 \\
\hline $\mathrm{K}_{2} \mathrm{O}$ & 10.24 & 0.13 & 10.37 & 0.19 & 10.41 & 0.13 \\
\hline \multirow[t]{2}{*}{$\mathrm{BaO}$} & 0.55 & 0.28 & 0.47 & 0.30 & & \\
\hline & 94.63 & 0.60 & 94.75 & 0.39 & 95.35 & 0.28 \\
\hline \multicolumn{7}{|c|}{ Atomic proportions based on 44 charges per formula unit } \\
\hline $\mathrm{Si}$ & 5.84 & 0.06 & 5.85 & 0.06 & 5.79 & 0.03 \\
\hline AI & 2.03 & 0.08 & 2.03 & 0.09 & 2,09 & 0.04 \\
\hline $\mathrm{Ti}$ & 0.21 & 0.03 & 0.24 & 0.05 & 0.23 & 0.03 \\
\hline $\mathrm{Cr}$ & 0.04 & 0.03 & 0.04 & 0.03 & 0.02 & 0.02 \\
\hline $\mathrm{Fe}^{2+}$ & 0.75 & 0.05 & 0.65 & 0.07 & 0.74 & 0.05 \\
\hline Mn & 0.01 & 0.01 & 0.01 & 0.01 & 0.01 & 0.01 \\
\hline $\mathrm{Ni}$ & 0.00 & 0.00 & 0.00 & 0.00 & 0.00 & 0.00 \\
\hline $\mathrm{Mg}$ & 5.04 & 0.10 & 5.07 & 0.08 & 5.04 & 0.08 \\
\hline $\mathrm{Ca}$ & 0.00 & 0.00 & 0.00 & 0.00 & 0.00 & 0.00 \\
\hline $\mathrm{Na}$ & 0.07 & 0.02 & 0.05 & 0.04 & 0.10 & 0.03 \\
\hline $\mathrm{K}$ & 1.90 & 0.02 & 1.92 & 0.02 & 1.91 & 0.02 \\
\hline $\mathrm{Ba}$ & 0,03 & 0.02 & 0.03 & 0.02 & & \\
\hline Mg no & 87.0 & & 88.6 & & 87.2 & \\
\hline
\end{tabular}

$\mathrm{Mg}$ no $=100 \mathrm{Mg} /(\mathrm{Mg}+\mathrm{Fe})$, calculated on average cation values. $\mathrm{Sdv}=$ standard deviation.

\section{Pyroxenes}

Pale-green aegirine-augite and colourless diopside are present in the lamproite of the central part of the stock, as well as in the central parts of many of the xenoliths (Table 1). Both minerals occur as single, up to $1 \mathrm{~mm}$ large, subhedral grains or in clusters of smaller grains. Orthopyroxene is absent.

Chemical compositions of the pyroxenes are given in Table 6 and Fig. 8.

The diopside is nearly pure $\mathrm{CaMgSi}_{2} \mathrm{O}_{6}$, with only a subordinate hedenbergite component. It is low in $\mathrm{Ti}$ (Table 6) compared with analyses from lamproites given by Mitchell (1985) and Bergman (1987).

Pale green aegirine-augites from the central matrix rock vary considerably, but generally have a large au- gite component. Bright green aegirine-augite rims the diopside in the cores of some xenoliths and is also found in small amounts in the matrix rock. It has a larger ratio of aegirine to augite than the pale green aegirine-augite, the composition is similar to the analysis given by Mitchell (1985, table X, analysis 3), see Fig. 8. Compared with published alkali pyroxene trends (e.g. Larsen, 1976) the aegirine-augites from Oqaitsúnguit are very low in $\mathrm{Fe}^{2+}+\mathrm{Mn}$.

\section{Amphiboles}

Two amphibole phases are present, a K-richterite and a K-Mg-arfvedsonite (Table 7 and Fig. 9). The first of these occurs as phenocrysts, as rims on diopside, and as late poikiloblastic grains. Compared with $\mathrm{K}$-richterite 
Table 4. Microprobe analyses of phlogopite nodules from lamproite stock at Oqaitsúnguit

\begin{tabular}{lrrrrrr}
\hline & \multicolumn{2}{c}{1} & \multicolumn{2}{c}{2} & \multicolumn{2}{c}{3} \\
& $\begin{array}{c}\text { average } \\
\mathrm{n}=19\end{array}$ & $\mathrm{sdv}$ & $\begin{array}{c}\text { average } \\
\mathrm{n}=3\end{array}$ & $\mathrm{sdv}$ & $\begin{array}{c}\text { average } \\
\mathrm{n}=2\end{array}$ & sdv \\
\hline $\mathrm{SiO}_{2}$ & 39.93 & 0.48 & 39.44 & 0.42 & 40.02 & 0.70 \\
$\mathrm{TiO}_{2}$ & 1.53 & 0.19 & 1.95 & 0.24 & 1.45 & 0.45 \\
$\mathrm{Al}_{2} \mathrm{O}_{3}$ & 12.26 & 0.31 & 12.20 & 0.08 & 12.10 & 0.35 \\
$\mathrm{Cr}_{2} \mathrm{O}_{3}$ & 0.06 & 0.12 & 0.55 & 0.08 & 0.01 & 0.00 \\
$\mathrm{FeO}$ & 4.45 & 0.41 & 5.46 & 0.15 & 4.65 & 0.38 \\
$\mathrm{MnO}$ & 0.06 & 0.07 & 0.06 & 0.05 & 0.01 & 0.00 \\
$\mathrm{NiO}$ & 0.00 & 0.00 & 0.00 & 0.00 & 0.00 & 0.00 \\
$\mathrm{MgO}$ & 24.68 & 0.39 & 23.04 & 0.04 & 24.63 & 0.39 \\
$\mathrm{CaO}$ & 0.02 & 0.03 & 0.01 & 0.00 & 0.01 & 0.00 \\
$\mathrm{Na} 2 \mathrm{O}$ & 0.20 & 0.12 & 0.14 & 0.06 & 0.19 & 0.03 \\
$\mathrm{~K}_{2} \mathrm{O}$ & 10.18 & 0.19 & 9.93 & 0.06 & 10.09 & 0.17 \\
$\mathrm{BaO}$ & 0.95 & 0.21 & 0.82 & 0.20 & 0.95 & 0.26 \\
& 94.31 & 1.03 & 93.60 & 0.77 & 94.09 & 0.13
\end{tabular}

Atomic proportions based on 44 charges per formula unit

\begin{tabular}{lllllll}
$\mathrm{Si}$ & 5.80 & 0.05 & 5.80 & 0.01 & 5.83 & 0.08 \\
$\mathrm{Al}$ & 2.10 & 0.05 & 2.11 & 0.02 & 2.08 & 0.07 \\
$\mathrm{Ti}$ & 0.17 & 0.02 & 0.22 & 0.03 & 0.16 & 0.05 \\
$\mathrm{Cr}$ & 0.01 & 0.01 & 0.06 & 0.01 & 0.00 & 0.00 \\
$\mathrm{Fe}^{2+}$ & 0.54 & 0.05 & 0.67 & 0.02 & 0.57 & 0.05 \\
$\mathrm{Mn}$ & 0.01 & 0.01 & 0.01 & 0.01 & 0.00 & 0.00 \\
$\mathrm{Ni}$ & 0.00 & 0.00 & 0.00 & 0.00 & 0.00 & 0.00 \\
$\mathrm{Mg}$ & 5.35 & 0.06 & 5.05 & 0.04 & 5.35 & 0.07 \\
$\mathrm{Ca}$ & 0.00 & 0.01 & 0.00 & 0.00 & 0.00 & 0.00 \\
$\mathrm{Na}$ & 0.06 & 0.03 & 0.04 & 0.02 & 0.05 & 0.01 \\
$\mathrm{~K}$ & 1.89 & 0.03 & 1.86 & 0.01 & 1.88 & 0.03 \\
$\mathrm{Ba}$ & 0.05 & 0.01 & 0.05 & 0.01 & 0.05 & 0.02 \\
$\mathrm{Mg} \mathrm{no}$ & 90.8 & & 88.3 & & 90.4 & \\
\hline
\end{tabular}

1: undifferentiated core and mantle analyses of a nodule.

2: core and 3: mantle of the nodule shown in Fig. 5 b.

See Table 3 for explanation.

from other lamproites (Mitchell, 1985; Bergman, 1987) it is high in $\mathrm{Si}, \mathrm{Fe}$ and $\mathrm{Mg}$, has a high $\mathrm{Mg}$ number and is extremely low in Ti (Fig. 9).

The K-Mg-arfvedsonite may, at least partly, be a secondary mineral as it occurs as rims on and as patches in $\mathrm{K}$-richterite and as fine-grained aggregates together with calcite. The central part of the lamproite stock contains very little K-Mg-arfvedsonite, but towards the margins of the stock this mineral becomes increasingly abundant in the matrix. The greatest concentrations occur in the outer rims of xenoliths (Table 1).

$\mathrm{K}-\mathrm{Mg}$-arfvedsonites are described from several lamproite localities (Brooks et al., 1978; Mitchell, 1985; Bergman, 1987). Compared with the K-Mg-arfvedsonites from lamproitic dykes in the Holsteinsborg area
(Brooks et al., 1978; Thy et al., 1987), the present ones are high in $\mathrm{Si}$ and $\mathrm{Mg}$ and low in $\mathrm{Al}, \mathrm{Fe}$ and $\mathrm{Ti}$.

The geochemistry of both the K-richterite and the $\mathrm{K}-\mathrm{Mg}$-arfvedsonite is unusual. The composition of the $\mathrm{K}$-Mg-arfvedsonite is close to the end member $\mathrm{KNa}_{2} \mathrm{Mg}_{4} \mathrm{Fe}^{3+} \mathrm{Si}_{8} \mathrm{O}_{22}(\mathrm{OH})_{2}$.

\section{Microcline}

Microcline is the only felsic mineral in the lamproite matrix as well as in most xenoliths (a few xenoliths contain quartz, Table 1). It shows cross-hatched twinning and has a large optical angle. It has a high concentration of $\mathrm{Fe}$; a feature that is also characteristic of some 


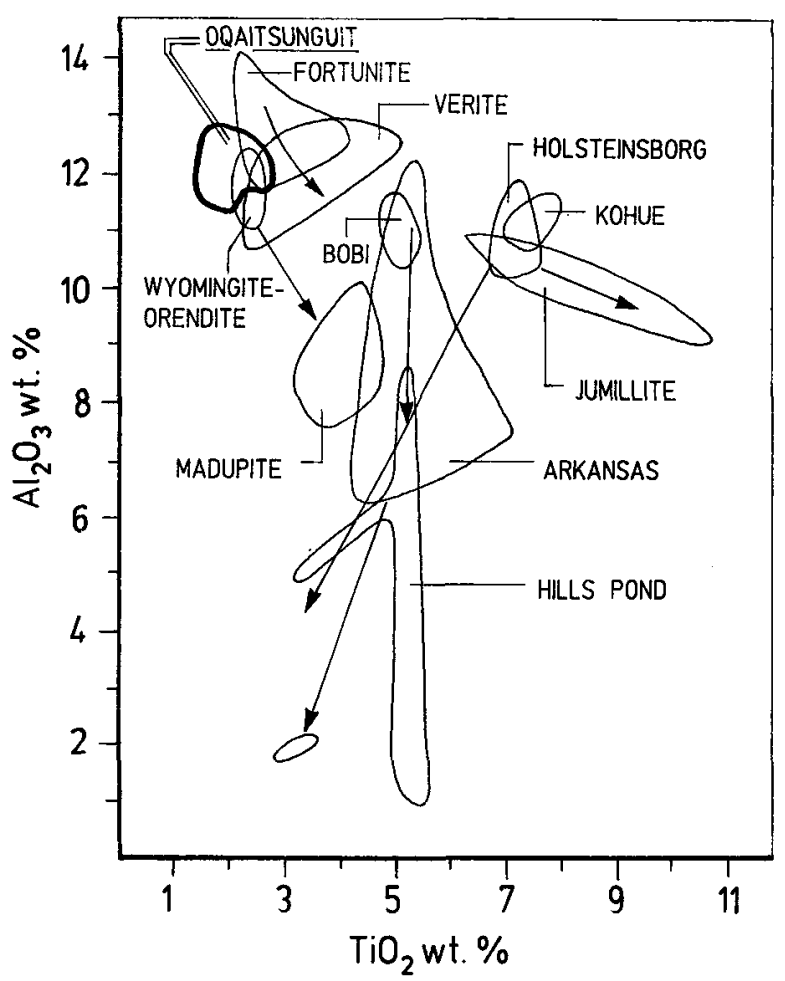

Fig. 6. Compositional variations $\left(\mathrm{Al}_{2} \mathrm{O}_{3}-\mathrm{TiO}_{2}\right)$ of phlogopites from the Oqaitsunguit lamproite compared with those from other occurrences and regions. Redrawn from fig. 10 in Mitchell (1985).

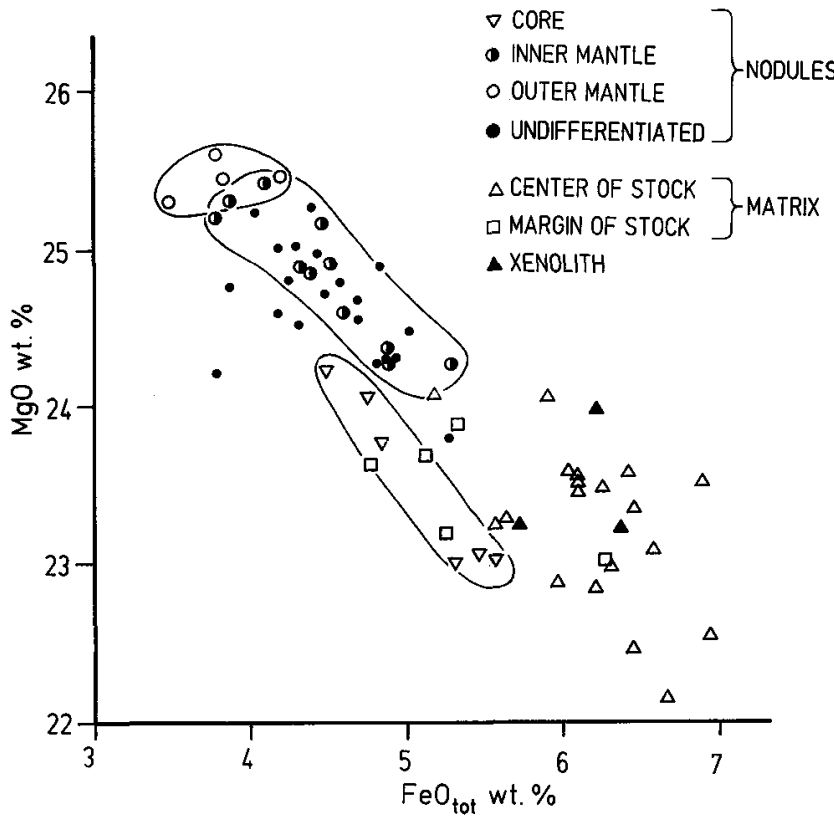

Fig. 7. Compositional variations $\left(\mathrm{MgO}-\mathrm{FeO}_{101}\right)$ of phlogopites from the Oqaitsúnguit lamproite. Outlined fields enclose analyses from core, inner and outer mantles of a nodule.

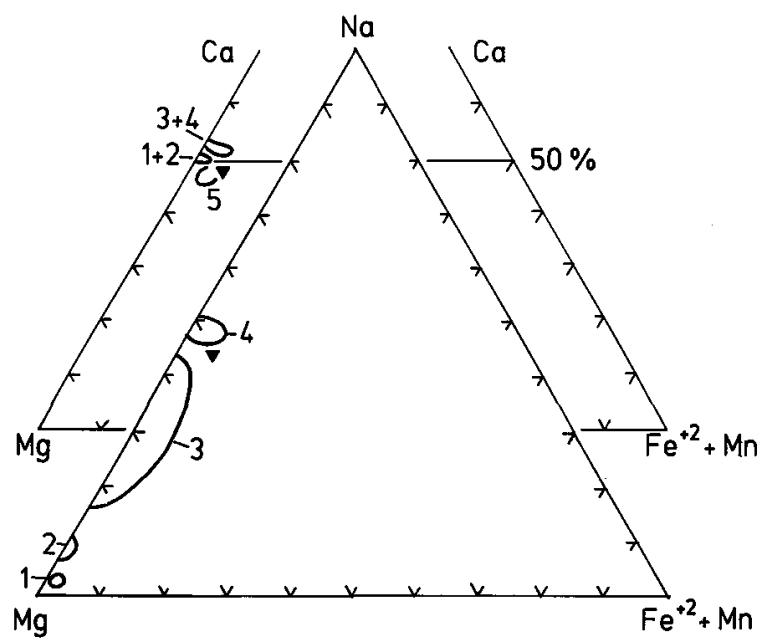

Fig. 8. Composition of pyroxenes from the Oqaitsúnguit lamproite compared with some from the West Kimberley region. 1: diopsides from centre of stock, 2: diopsides from a xenolith, 3: aegirine-augites from centre of stock, 4: aegirine-augites from a xenolith, all from Oqaitsúnguit. 5: pyroxenes from phlogopite-lamproites from West Kimberley (from fig. 12 in Mitchell, 1985). The filled triangle represents an aegirine-augite from West Kimberley (table X, analysis 3 in Mitchell, 1985).

sanidines from lamproites mentioned by Bergman (1987).

The grain size of the microcline in the matrix often exceeds $1 \mathrm{~cm}$, but the grains are internally subdivided into sub-grains with slightly differing lattice orientations.

The microcline seems to have crystallised mainly as a late phase and encloses all other mineral phases. However, a few small irregular grains of microcline are themselves enclosed in some of the central phlogopite grains of the nodules and in a few phlogopite grains of the matrix rock.

Microcline is a rather unusual component of lamproites. The most common feldspar in such rocks is sanidine (Mitchell, 1985; Bergmann, 1987; Thy et al., 1987) which is often considered to be a pseudomorph after leucite. In the Oqaitsúnguit lamproite no evidence has been found for an origin of the microcline other than by primary, although late, crystallisation. The composition of the microcline is shown in Table 8 .

\section{Apatite}

All samples of the lamproite, as well as of the xenoliths, contain apatite. In the lamproite apatite constitutes as much as $5-10 \%$ of the rock. It occurs as subhedral prisms up to $1 \mathrm{~mm}$ long and $0.3 \mathrm{~mm}$ across. 
Table 5. Microprobe analyses from core, inner and outer mantle of a phlogopite nodule from lamproite stock at Oqaitsúnguit

\begin{tabular}{|c|c|c|c|c|c|c|}
\hline & \multicolumn{2}{|c|}{ core } & \multicolumn{2}{|c|}{ inner mantle } & \multicolumn{2}{|c|}{ outer mantle } \\
\hline & $\begin{array}{c}\text { average } \\
\mathrm{n}=3\end{array}$ & sdv & $\begin{array}{c}\text { average } \\
n=6\end{array}$ & $s d v$ & $\begin{array}{c}\text { average } \\
n=4\end{array}$ & sdv \\
\hline $\mathrm{SiO}_{2}$ & 39.78 & 0.37 & 39.94 & 0.33 & 39.88 & 0.14 \\
\hline $\mathrm{TiO}_{2}$ & 2.22 & 0.06 & 1.85 & 0.10 & 1.72 & 0.10 \\
\hline $\mathrm{Al}_{2} \mathrm{O}_{3}$ & 12.48 & 0.05 & 12.50 & 0.26 & 12.46 & 0.09 \\
\hline $\mathrm{Cr}_{2} \mathrm{O}_{3}$ & 0.72 & 0.14 & 0.10 & 0.10 & 0.05 & 0.08 \\
\hline $\mathrm{FeO}$ & 4.69 & 0.18 & 4.35 & 0.56 & 3.84 & 0.29 \\
\hline $\mathrm{MnO}$ & 0.06 & 0.09 & 0.10 & 0.10 & 0.01 & 0.00 \\
\hline $\mathrm{NiO}$ & 0.07 & 0.11 & 0.10 & 0.14 & 0.13 & 0.14 \\
\hline $\mathrm{MgO}$ & 24.00 & 0.24 & 25.03 & 0.43 & 25.46 & 0.12 \\
\hline $\mathrm{CaO}$ & 0.07 & 0.05 & 0.09 & 0.14 & 0.05 & 0.07 \\
\hline $\mathrm{Na}_{2} \mathrm{O}$ & 0.32 & 0.05 & 0.46 & 0.11 & 0.39 & 0.05 \\
\hline \multirow[t]{2}{*}{$\mathrm{K}_{2} \mathrm{O}$} & 10.35 & 0.16 & 10.07 & 0.23 & 10.37 & 0.13 \\
\hline & 94.77 & 0.36 & $\overline{94.59}$ & 0.64 & 94.35 & 0.31 \\
\hline \multicolumn{7}{|c|}{ Atomic proportions based on 44 charges per formula unit } \\
\hline $\mathrm{Si}$ & 5.73 & 0.04 & 5.74 & 0.04 & 5.74 & 0.02 \\
\hline $\mathrm{Al}$ & 2.12 & 0.01 & 2.12 & 0.04 & 2.11 & 0.01 \\
\hline $\mathrm{Ti}$ & 0.24 & 0.01 & 0.20 & 0.01 & 0.19 & 0.01 \\
\hline $\mathrm{Cr}$ & 0.08 & 0.02 & 0.01 & 0.01 & 0.01 & 0.01 \\
\hline $\mathrm{Fe}^{2+}$ & 0.57 & 0.02 & 0.52 & 0.07 & 0.46 & 0.04 \\
\hline $\mathrm{Mn}$ & 0.01 & 0.01 & 0.01 & 0.01 & 0.00 & 0.00 \\
\hline $\mathrm{Ni}$ & 0.01 & 0.01 & 0.01 & 0.02 & 0.01 & 0.02 \\
\hline $\mathrm{Mg}$ & 5.16 & 0.03 & 5.37 & 0.08 & 5.47 & 0.01 \\
\hline $\mathrm{Ca}$ & 0.01 & 0.01 & 0.01 & 0.02 & 0.01 & 0.01 \\
\hline $\mathrm{Na}$ & 0.09 & 0.01 & 0.13 & 0.03 & 0.11 & 0.01 \\
\hline $\mathrm{K}$ & 1.90 & 0.03 & 1.85 & 0.04 & 1.91 & 0.02 \\
\hline Mg no & 90.1 & & 91.2 & & 92.2 & \\
\hline
\end{tabular}

The analyses are from the same nodule as 1 in Table 4, but in this series of analyses, Ba was not analysed. See Table 3 for explanation.

\section{Sphene and rutile}

Sphene and rutile are accessory minerals (their optical identification was confirmed by the microprobe analyses). Sphene occurs as irregular grains up to $1 \mathrm{~mm}$ across, while rutile forms prismatic grains. Small irregular grains of sphene are enclosed in the central grain of some phlogopite nodules. The occurrence of sphene and rutile is rather extraordinary in a rock with abnormally low $\mathrm{Ti}$ contents in the other minerals.

\section{Calcite}

Most samples contain calcite (Table 1). While some calcite seems to have crystallised as a primary mineral since it is found included in phlogopites, some of it probably formed together with $\mathrm{K}-\mathrm{Mg}$-arfvedsonite by replacement of diopside. The largest amounts and the largest grains (up to $1 \mathrm{~mm}$ ) are found in xenoliths.

\section{Opaque minerals}

Opaque minerals are only present in the matrix as rare and small anhedral grains, amounting to less than $0.1 \%$ of the total rock volume. In some xenoliths opaque minerals are more abundant, but in the xenoliths that were analysed only a few grains are present, and these all consist of hematite, which seems to be pseudomorphous after magnetite. 

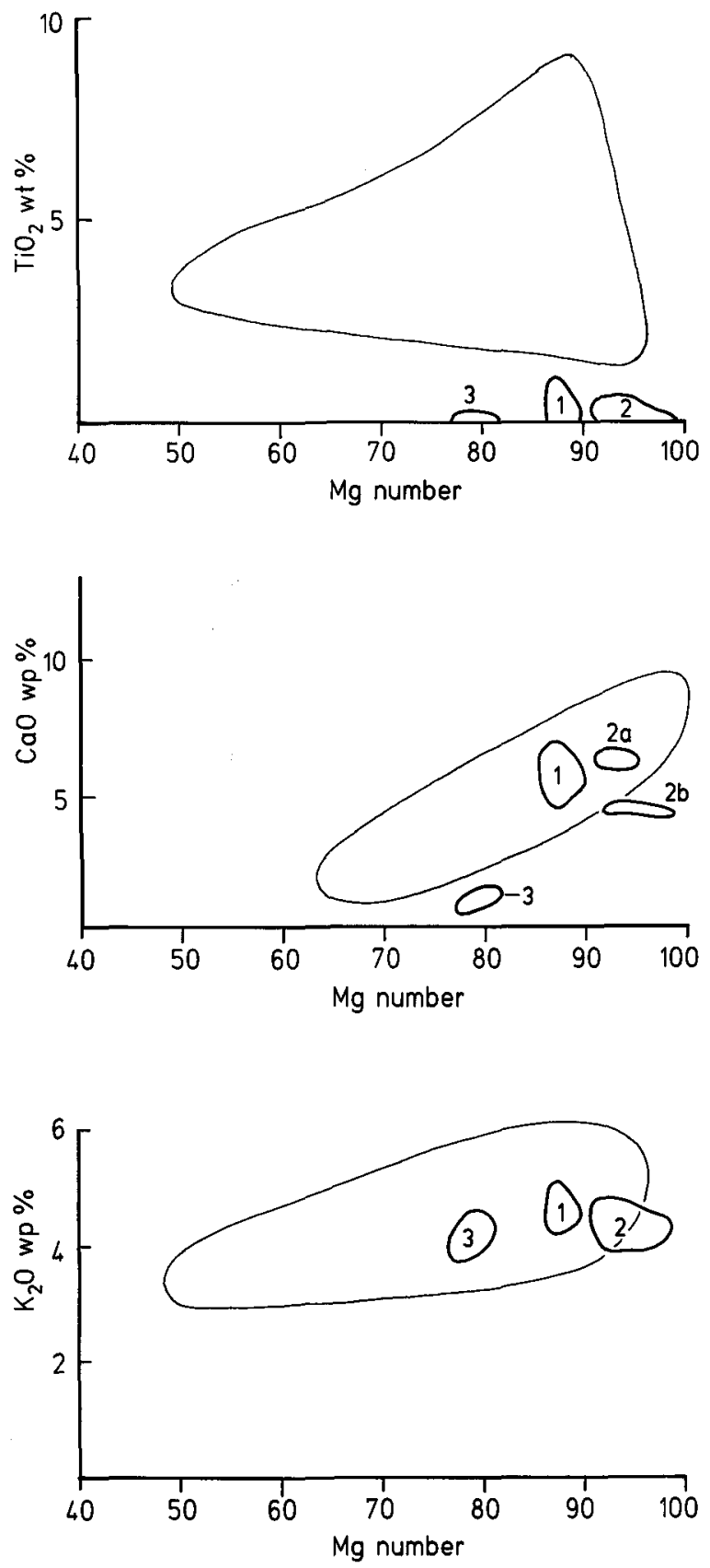

Fig. 9. Compositions of amphiboles from the Oqaitsúnguit lamproite compared with compositions from other lamproites. 1: K-richterites from central and marginal parts of stock, 2: K-richterites from xenoliths ( $\mathrm{a}$ and $\mathbf{b}$ are different xenoliths), 3 : $\mathrm{K}-\mathrm{Mg}$ arfvedsonites from a xenolith. $\mathrm{Mg}$ number: $100 \mathrm{Mg} /(\mathrm{Mg}$ $+\mathrm{Fe}^{2+}$ ). Thin lines are from Bergman (1987, fig. 24) and enclose $90 \%$ of his data for lamproite amphiboles.

\section{Discussion}

The grain size, mineralogy and mineral chemistry of the Oqaitsúnguit lamproite are unusual. Moreover, the conspicuous phlogopite nodules and their crystallographic structure are highly exceptional and make the occurrence unique.

Only one published description of phlogopite nodules which are similar to those from Oqaitsúnguit is known to the author. Le Cheminant \& Le Cheminant (1985) mention inclusions of ovoid phlogopite megacrysts ('eggs') up to $3 \mathrm{~cm}$ long in $1.8 \mathrm{Ga}$ lamprophyre and trachyandesite dykes and one flow in the Baker region, Keewatin district, Canada. Most of the 'eggs' have a thick concentric jacket of high $\mathrm{Mg}, \mathrm{Cr}$ and Ni phlogopite enclosing a megacryst core of similar composition. Ti-rich micas $\left(4-8 \% \mathrm{TiO}_{2}\right)$ occur as xenocrystic cores with mantles of high $\mathrm{Mg}$ phlogopite.

$\mathrm{He}$ (1984) described large ellipsoidal phlogopite grains from a kimberlite in northern China as being large phlogopite grains with rounded corners.

The Geological Museum in Copenhagen has a single nodule that is very similar to those from Oqaitsúnguit, but there is no record of its origin. Five samples of 3-5 $\mathrm{cm}$ large spheroidal biotite nodules from Greenland were described by Bøggild (1953), but although they superficially resemble the phlogopite nodules they differ by having a central core of granitic material and by being more irregular. Nothing is known about their manner of occurrence.

Mica balls have been described from a locality at Hermanslag in Mähren, Czechoslovakia (Burkart, 1953). They have an inner mantle of phlogopite wrapped around a core of pegmatitic material and an outer mantle of radiating anthophyllite. They occur in a pegmatite dyke.

None of the descriptions mentioned above include suggestions as to the origin of the nodules.

The phlogopite nodules are comagmatic and have formed at an early stage of the crystallisation of the lamproite. Their origin, however, remains a mystery. A plausible, explanation of their formation may be that early phenocrysts were formed by homogeneous nucleation, and that gas-streaming kept these in rotation during the growth of the mantles.

Rocks similar to the Oqaitsúnguit lamproite probably weather rather easily in most climates (Rock, 1990). However, the appearance of the nodules is so remarkable that in inhabited areas such occurrences would hardly have escaped notice if they existed. 
Table 6. Microprobe analyses of pyroxenes from centre of lamproite stock at Oqaitsúnguit and from a xenolith in the stock

\begin{tabular}{|c|c|c|c|c|c|c|c|c|}
\hline & \multicolumn{4}{|c|}{ Aegirine-augites } & \multicolumn{4}{|c|}{ Diopsides } \\
\hline & \multicolumn{2}{|c|}{$\begin{array}{c}\text { centre } \\
\text { of stock }\end{array}$} & \multicolumn{2}{|c|}{ xenolith } & \multicolumn{2}{|c|}{$\begin{array}{l}\text { centre } \\
\text { of stock }\end{array}$} & \multicolumn{2}{|c|}{ xenolith } \\
\hline & $\begin{array}{c}\text { average } \\
n=26\end{array}$ & $s d v$ & $\begin{array}{c}\text { average } \\
n=6\end{array}$ & sdv & $\begin{array}{c}\text { average } \\
\mathrm{n}=12\end{array}$ & sdv & $\begin{array}{c}\text { average } \\
n=6\end{array}$ & $\mathrm{sdv}$ \\
\hline $\mathrm{SiO}_{2}$ & 54.33 & 0.34 & 54.02 & 0.29 & 54.88 & 0.14 & 54.96 & 0.26 \\
\hline $\mathrm{TiO}_{2}$ & 0.09 & 0.04 & 1.30 & 0.39 & 0.21 & 0.08 & 0.17 & 0.09 \\
\hline $\mathrm{Al}_{2} \mathrm{O}_{3}$ & 0.15 & 0.13 & 0.03 & 0.06 & 0.04 & 0.05 & 0.06 & 0.09 \\
\hline $\mathrm{Cr}_{2} \mathrm{O}_{3}$ & 0.28 & 0.07 & 0.30 & 0.14 & 0.21 & 0.06 & 0.65 & 0.31 \\
\hline $\mathrm{FeO}$ & 9.78 & 1.55 & 14.96 & 0.42 & 2.69 & 0.44 & 2.89 & 0.31 \\
\hline $\mathrm{MnO}$ & 0.07 & 0.08 & 0.07 & 0.10 & 0.04 & 0.05 & 0.12 & 0.12 \\
\hline $\mathrm{NiO}$ & 0.00 & 0.00 & 0.18 & 0.19 & 0.00 & 0.00 & 0.20 & 0.15 \\
\hline $\mathrm{MgO}$ & 12.18 & 1.09 & 8.71 & 0.63 & 17.55 & 0.34 & 17.06 & 0.30 \\
\hline $\mathrm{CaO}$ & 18.46 & 1.69 & 13.41 & 1.04 & 24.86 & 0.42 & 23.81 & 0.42 \\
\hline $\mathrm{Na}_{2} \mathrm{O}$ & 4.01 & 0.84 & 6.92 & 0.51 & 0.47 & 0.27 & 1.18 & 0.21 \\
\hline \multirow[t]{2}{*}{$\mathrm{K}_{2} \mathrm{O}$} & 0.01 & 0.01 & 0.03 & 0.05 & 0.00 & 0.00 & 0.01 & 0.00 \\
\hline & 99.41 & 0.63 & $\overline{99.82}$ & 0.95 & $\overline{101.02}$ & 0.40 & $\overline{100.83}$ & 0.75 \\
\hline $\mathrm{FeO}$ & 1.02 & 0.52 & 0.94 & 0.81 & 0.46 & 0.35 & 0.09 & 0.22 \\
\hline \multirow[t]{2}{*}{$\mathrm{Fe}_{2} \mathrm{O}_{3}$} & 9.74 & 1.83 & 15.59 & 0.95 & 2.48 & 0.70 & 3.11 & 0.16 \\
\hline & $\overline{100.38}$ & 0.58 & $\overline{101.39}$ & 0.10 & $\overline{101.27}$ & 0.43 & $\overline{101.14}$ & 0.02 \\
\hline \multicolumn{9}{|c|}{ Atomic proportions based on 4 charges per formula unit } \\
\hline $\mathrm{Si}$ & 2.00 & 0.01 & 1.99 & 0.02 & 1.97 & 0.01 & 1.98 & 0.01 \\
\hline $\mathrm{Al}^{\mathrm{IV}}$ & 0.00 & 0.00 & 0.00 & 0.00 & 0.00 & 0.00 & 0.00 & 0.00 \\
\hline $\mathrm{Al}^{\mathrm{VI}}$ & 0.01 & 0.01 & 0.00 & 0.00 & 0.00 & 0.00 & 0.00 & 0.00 \\
\hline $\mathrm{Ti}$ & 0.00 & 0.00 & 0.04 & 0.01 & 0.01 & 0.00 & 0.00 & 0.00 \\
\hline $\mathrm{Cr}$ & 0.01 & 0.00 & 0.01 & 0.00 & 0.01 & 0.00 & 0.02 & 0.01 \\
\hline $\mathrm{Fe}^{2+}$ & 0.03 & 0.02 & 0.03 & 0.02 & 0.01 & 0.01 & 0.00 & 0.01 \\
\hline $\mathrm{Fe}^{3+}$ & 0.27 & 0.05 & 0.43 & 0.02 & 0.07 & 0.02 & 0.84 & 0.00 \\
\hline $\mathrm{Mn}$ & 0.00 & 0.00 & 0.00 & 0.00 & 0.00 & 0.00 & 0.00 & 0.00 \\
\hline $\mathrm{Ni}$ & 0.00 & 0.00 & 0.00 & 0.01 & 0.00 & 0.00 & 0.01 & 0.01 \\
\hline $\mathrm{Mg}$ & 0.67 & 0.06 & 0.48 & 0.03 & 0.94 & 0.02 & 0.91 & 0.01 \\
\hline $\mathrm{Ca}$ & 0.73 & 0.06 & 0.53 & 0.04 & 0.96 & 0.02 & 0.91 & 0.01 \\
\hline $\mathrm{Na}$ & 0.29 & 0.06 & 0.49 & 0.04 & 0.03 & 0.02 & 0.08 & 0.02 \\
\hline $\mathrm{K}$ & 0.00 & 0.00 & 0.00 & 0.00 & 0.00 & 0.00 & 0.00 & 0.00 \\
\hline $\mathrm{Mg}$ no & 95.7 & & 94.1 & & 98.9 & & 100.0 & \\
\hline
\end{tabular}

See Table 3 for explanation.

Acknowledgements. The Oqaitsúnguit stock was discovered while the author took part in a joint project between the Geological Survey of Greenland and the Geological Institute, University of Copenhagen.

The field work was funded by the Danish Natural Science Research Council.
Thanks are especially due to Lotte Melchior Larsen and Richard Wilson for many valuable suggestions for improvement of the manuscript, to David Rex and Henrik Rasmussen for permission to cite the K-Ar ages and to Jørn Rønsbo for help with the microprobe analyses. Lis Friberg assisted in the field and René Madsen drafted the figures. 
Table 7. Microprobe analyses of amphiboles from lamproite stock at Oqaitsúnguit

\begin{tabular}{|c|c|c|c|c|c|c|c|c|c|c|c|c|}
\hline \multicolumn{11}{|c|}{ K-richterites } & \multirow{2}{*}{\multicolumn{2}{|c|}{$\frac{\text { K-Mg-arfv. }}{\text { xenolith }}$}} \\
\hline & \multicolumn{2}{|c|}{$\begin{array}{c}\text { centre } \\
\text { of stock }\end{array}$} & \multicolumn{2}{|c|}{$\begin{array}{l}\text { margin } \\
\text { of stock }\end{array}$} & \multicolumn{2}{|c|}{ xenolith } & \multicolumn{2}{|c|}{ xenolith } & \multicolumn{2}{|c|}{ rim on diop. } & & \\
\hline & $\begin{array}{c}\text { average } \\
n=9\end{array}$ & sdv & $\begin{array}{c}\text { average } \\
n=4\end{array}$ & sdv & $\begin{array}{c}\text { average } \\
\mathrm{n}=8\end{array}$ & sdv & $\begin{array}{c}\text { average } \\
\mathrm{n}=7\end{array}$ & $\mathrm{sdv}$ & $\begin{array}{c}\text { average } \\
\mathrm{n}=3\end{array}$ & sdv & $\begin{array}{c}\text { average } \\
\mathrm{n}=7\end{array}$ & $s d v$ \\
\hline $\mathrm{SiO}_{2}$ & 54.90 & 0.65 & 55.52 & 0.18 & 55.89 & 0.61 & 56.85 & 0.49 & 56.86 & 0.20 & 56.23 & 0.59 \\
\hline $\mathrm{TiO}_{2}$ & 0.70 & 0.50 & 0.54 & 0.16 & 0.34 & 0.17 & 0.10 & 0.14 & 0.13 & 0.05 & 0.14 & 0.07 \\
\hline $\mathrm{Al}_{2} \mathrm{O}_{3}$ & 0.44 & 0.28 & 0.30 & 0.18 & 0.31 & 0.21 & 0.34 & 0.06 & 0.00 & 0.00 & 0.04 & 0.05 \\
\hline $\mathrm{Cr}_{2} \mathrm{O}_{3}$ & 0.13 & 0.04 & 0.18 & 0.05 & 0.10 & 0.10 & 0.13 & 0.12 & 0.15 & 0.06 & 0.22 & 0.22 \\
\hline $\mathrm{FeO}$ & 5.10 & 0.50 & 5.01 & 0.29 & 5.97 & 2.19 & 4.54 & 0.46 & 5.32 & 0.39 & 8.76 & 0.73 \\
\hline $\mathrm{MnO}$ & 0.12 & 0.08 & 0.12 & 0.13 & 0.08 & 0.09 & 0.57 & 0.11 & 0.05 & 0.07 & 0.03 & 0.06 \\
\hline $\mathrm{NiO}$ & 0.00 & 0.00 & 0.00 & 0.00 & 0.01 & 0.00 & 0.17 & 0.16 & 0.00 & 0.00 & 0.00 & 0.00 \\
\hline $\mathrm{MgO}$ & 20.63 & 0.54 & 20.81 & 0.03 & 20.49 & 1.40 & 20.99 & 0.26 & 21.81 & 0.12 & 18.48 & 0.24 \\
\hline $\mathrm{CaO}$ & 6.18 & 0.76 & 6.08 & 0.09 & 4.93 & 2.67 & 4.40 & 0.18 & 6.12 & 0.09 & 1.04 & 0.39 \\
\hline $\mathrm{Na}_{2} \mathrm{O}$ & 4.22 & 0.43 & 4.27 & 0.23 & 5.31 & 1.66 & 5.94 & 0.33 & 4.76 & 0.31 & 7.44 & 0.43 \\
\hline \multirow[t]{2}{*}{$\mathrm{K}_{2} \mathrm{O}$} & 4.36 & 0.06 & 4.59 & 0.15 & 4.41 & 0.28 & 4.39 & 0.16 & 1.99 & 0.18 & 4.26 & 0.35 \\
\hline & $\overline{96.78}$ & 0.92 & $\overline{97.43}$ & 0.43 & 97.81 & 0.58 & $\overline{98.10}$ & 0.74 & 96.40 & 0.63 & 96.64 & 0.93 \\
\hline $\mathrm{FeO}$ & & & & & 2.82 & 0.54 & 1.90 & 0.99 & & & 2.61 & \\
\hline \multirow[t]{2}{*}{$\mathrm{Fe}_{2} \mathrm{O}_{3}$} & & & & & 3.50 & 2.90 & 2.49 & 1.13 & & & 6.83 & \\
\hline & & & & & 98.16 & 0.50 & 98.40 & 0.93 & & & 97.32 & \\
\hline \multicolumn{13}{|c|}{ Atomic proportions based on 16 charges per formula unit } \\
\hline $\mathrm{Si}$ & 7.87 & 0.09 & 7.91 & 0.03 & 7.89 & 0.09 & 7.97 & 0.03 & 8.05 & 0.01 & 8.00 & 0.03 \\
\hline $\mathrm{Al}$ & 0.07 & 0.05 & 0.05 & 0.03 & 0.05 & 0.04 & 0.01 & 0.01 & 0.00 & 0.00 & 0.01 & 0.01 \\
\hline $\mathrm{Ti}$ & 0.07 & 0.05 & 0.06 & 0.02 & 0.04 & 0.09 & 0.01 & 0.01 & 0.01 & 0.00 & 0.01 & 0.01 \\
\hline $\mathrm{Cr}$ & 0.01 & 0.00 & 0.02 & 0.00 & 0.01 & 0.01 & 0.01 & 0.01 & 0.02 & 0.01 & 0.02 & 0.03 \\
\hline $\mathrm{Fe}^{2+}$ & 0.61 & 0.06 & 0.60 & 0.03 & 0.33 & 0.08 & 0.22 & 0.12 & 0.63 & 0.04 & 0.31 & \\
\hline $\mathrm{Fe}^{3+}$ & & & & & 0.37 & 0.31 & 0.31 & 0.12 & & & 0.73 & \\
\hline $\mathrm{Mn}$ & 0.01 & 0.01 & 0.01 & 0.01 & 0.01 & 0.01 & 0.07 & 0.01 & 0.01 & 0.01 & 0.00 & 0.01 \\
\hline $\mathrm{Ni}$ & 0.00 & 0.00 & 0.00 & 0.00 & 0.00 & 0.00 & 0.02 & 0.02 & 0.00 & 0.00 & 0.00 & 0.00 \\
\hline $\mathrm{Mg}$ & 4.41 & 0.10 & 4.42 & 0.01 & 4.31 & 0.29 & 4.39 & 0.07 & 4.44 & 0.04 & 3.92 & 0.07 \\
\hline $\mathrm{Ca}$ & 0.95 & 0.11 & 0.93 & 0.01 & 0.74 & 0.40 & 0.66 & 0.03 & 0.93 & 0.02 & 0.16 & 0.06 \\
\hline $\mathrm{Na}$ & 1.17 & 0.12 & 1.18 & 0.06 & 1.45 & 0.45 & 1.61 & 0.09 & 1.31 & 0.08 & 2.06 & 0.11 \\
\hline $\mathrm{K}$ & 0.80 & 0.03 & 0.83 & 0.03 & 1.45 & 0.45 & 0.79 & 0.03 & 0.36 & 0.03 & 0.78 & 0.07 \\
\hline $\mathrm{Mg}$ no & 87.8 & 0.01 & 88.1 & 0.01 & 92.9 & 0.01 & 95.2 & 0.02 & 87.6 & 0.01 & 92.7 & \\
\hline
\end{tabular}

See Table 3 for explanation.

\section{References}

Bergman, S. C. 1987: Lamproites and other potassium-rich igneous rocks: a review of their occurrence, mineralogy and geochemistry. In Fitton, J. G. \& Upton, B. G. J. (ed.) Alkaline igneous rocks. Spec. Publ. geol. Soc. Lond. 30, 103-190.

Bøggild, O. B. 1953: The mineralogy of Greenland. Meddr Grønland 149(3), 442 pp.

Brooks, C. K., Noe-Nygaard, A., Rex, D. C. \& Rønsbo, J. R. 1978: An occurrence of ultrapotassic dikes in the neighbourhood of Holsteinsborg, West Greenland. Bull. geol. Soc. Denmark 27, 1-8.
Burkart, E. 1953: Mährens Minerale und ihre Literatur, 1004 pp. Praha.

Dawson, J. B. 1987: The kimberlite clan: relationship with olivine and leucite lamproites, and inferences for uppermantle metasomatism. In Fitton, J. G. \& Upton, B. G. J. (ed.) Alkaline igneous rocks. Spec. Publ. geol. Soc. Lond. 30, 95-101.

Escher, A. \& Burri, M. 1967: Stratigraphy and structural development of the Precambrian rocks in the area north-east of Disko Bugt, West Greenland. Rapp. Grønlands geol. Unders. 13, 28 pp. 
Table 8. Microprobe analyses of microclines in lamproite from central and marginal parts and in a xenolith from lamproite stock at Oqaitsúnguit

\begin{tabular}{|c|c|c|c|c|c|c|}
\hline & \multicolumn{2}{|c|}{$\begin{array}{l}\text { centre } \\
\text { of stock }\end{array}$} & \multicolumn{2}{|c|}{$\begin{array}{l}\text { margin } \\
\text { of stock }\end{array}$} & \multicolumn{2}{|c|}{ xenolith } \\
\hline & $\begin{array}{c}\text { average } \\
n=15\end{array}$ & sdv & $\begin{array}{c}\text { average } \\
n=6\end{array}$ & sdv & $\begin{array}{c}\text { average } \\
n=6\end{array}$ & $\mathrm{sdv}$ \\
\hline $\mathrm{SiO}_{2}$ & 63.29 & 0.36 & 63.93 & 0.24 & 64.67 & 0.36 \\
\hline $\mathrm{TiO}_{2}$ & 0.10 & 0.05 & 0.04 & 0.04 & 0.05 & 0.06 \\
\hline $\mathrm{Al}_{2} \mathrm{O}_{3}$ & 18.12 & 0.21 & 18.06 & 0.16 & 17.86 & 0.13 \\
\hline $\mathrm{FeO}$ & 0.67 & 0.12 & 0.71 & 0.18 & 0.74 & 0.12 \\
\hline $\mathrm{MgO}$ & 0.00 & 0.00 & 0.00 & 0.00 & 0.06 & 0.07 \\
\hline $\mathrm{CaO}$ & 0.01 & 0.02 & 0.00 & 0.00 & 0.01 & 0.00 \\
\hline $\mathrm{Na}_{2} \mathrm{O}$ & 0.36 & 0.08 & 0.30 & 0.05 & 0.51 & 0.14 \\
\hline $\mathrm{K}_{2} \mathrm{O}$ & 15.81 & 0.23 & 16.17 & 0.11 & 16.11 & 0.30 \\
\hline \multirow[t]{2}{*}{$\mathrm{BaO}$} & 0.18 & 0.37 & 0.56 & 0.10 & & \\
\hline & 99.55 & 0.42 & 99.80 & 0.38 & 99.99 & 0.60 \\
\hline \multicolumn{5}{|c|}{ Atomic proportions based on 8 charges per formula unit } & & \\
\hline $\mathrm{Si}$ & 2.97 & 0.01 & 2.99 & 0.00 & 3.00 & 0.01 \\
\hline $\mathrm{Al}$ & 1.00 & 0.01 & 0.99 & 0.01 & 0.98 & 0.01 \\
\hline $\mathrm{Ti}$ & 0.00 & 0.00 & 0.00 & 0.00 & 0.00 & 0.00 \\
\hline $\mathrm{Fe}^{2+}$ & 0.03 & 0.01 & 0.03 & 0.01 & 0.03 & 0.01 \\
\hline $\mathrm{Mg}$ & 0.00 & 0.00 & 0.00 & 0.00 & 0.00 & 0.01 \\
\hline $\mathrm{Ca}$ & 0.00 & 0.00 & 0.00 & 0.00 & 0.00 & 0.00 \\
\hline $\mathrm{Na}$ & 0.03 & 0.01 & 0.03 & 0.00 & 0.05 & 0.01 \\
\hline $\mathrm{Ka}$ & 0.95 & 0.01 & 0.96 & 0.01 & 0.95 & 0.02 \\
\hline $\mathrm{Ba}$ & 0.02 & 0.01 & 0.01 & 0.00 & & \\
\hline Or & 94.53 & 1.22 & 96.24 & 0.52 & 95.41 & 1.20 \\
\hline $\mathrm{Ab}$ & 3.24 & 0.74 & 2.68 & 0.44 & 4.54 & 1.20 \\
\hline An & 0.07 & 0.08 & 0.05 & 0.00 & 0.05 & 0.00 \\
\hline
\end{tabular}

See Table 3 for explanation.

He G.-Z. 1984: Kimberlites in China and their major components, a discussion on the physico-chemical properties of the upper mantle. In Kornprobst, J. (ed.) Kimberlites; I, Kimberlites and related rocks. Developments in petrology $11 \mathrm{~A}$, 181-194. Amsterdam: Elsevier Sci. Publ.

Kalsbeek, F., Taylor, P. N. \& Pidgeon, R. T. 1988: Unreworked Archean basement and Proterozoic supracrustal rocks from northeastern Disko Bugt, West Greenland: implications for the nature of the Proterozoic mobile belts in Greenland. Can. J. Earth Sci. 25, 773-782.

Knudsen, C., Appel, P. W. U., Hageskov, B. \& Skjernaa, L. 1988: Geological reconnaissance in the Precambrian basement of the Atâ area, central West Greenland. Rapp. Grønlands geol. Unders. 140, 9-17.

Larsen, L. M. 1976: Clinopyroxenes and coexisting mafic minerals from the alkaline Ilímaussaq intrusion, South Greenland. J. Petrol. 17, 258-290.

Larsen, L. M. \& Rex, D. C. in press: A review of the $2500 \mathrm{Ma}$ span of alkaline-ultramafic, potassic and carbonatitic magmatism in West Greenland. Lithos.
Le Cheminant, A. N. \& Le Cheminant, G. M. 1985: Phlogopite from $1.8 \mathrm{Ga}$ lamprophyres and trachyandesites, district of Keewatin: petrologic implications. Prog. Abstr. geol. Soc. Can. Ann. Meet. (Fredericton, N.B.) 1985, A33 only.

Marker, M. \& Knudsen, C. 1989: Middle Proterozoic ultramafic lamprophyre dykes in the Archean of the Atâ area, central West Greenland. Rapp. Grønlands geol. Unders. 145, 23-28

Mitchell, R. H. 1985: A review of the mineralogy of lamproites. Trans. geol. Soc. S. Afr. 88, 411-437.

Rock, N. M. S. 1987: The nature and origin of lamprophyres: an overview. In Fitton, J. G. \& Upton, B. G. J. (ed.) Alkaline igneous rocks. Spec. Publ. geol. Soc. Lond. 30, 191226.

Rock, N. M. S. 1990: Lamprophyric dyke swarms and pipes in Western Australia: an updated summary. In Parker, A. J., Richwood, P. C. \& Tucker, D. H. (ed.) Mafic dykes and emplacement mechanisms, 201-205. Rotterdam: Balkema.

Scott, B. H. 1979: Petrogenesis of kimberlites and associated potassic lamprophyres from central West Greenland. In 
Boyd, F. R. \& Meyer, H. O. A. (ed.) Kimberlites, diatremes and diamonds, 190-205. Washington: American Geophysical Union.

Scott, B. H. 1981: Kimberlite and lamproite dykes from Holsteinsborg, West Greenland. Meddr Grønland Geosci. 4, 24 pp.

Thy, P. \& Wilson, J. R. 1980: Primary igneous load-cast defor- mation structures in Fongen-Hyllingen layered basic intrusion, Trondheim region, Norway. Geol. Mag 117, 363-371. Thy, P., Stecher, O. \& Korstgård, J. A. 1987: Mineral chemistry and crystallization sequences in kimberlite and lamproite dikes from the Sisimut area, central West Greenland. Lithos 20, 391-417. 